\title{
ALAT TANGKAP UDANG DOGOL (Metapenaeus ensis De Haan) YANG LAYAK DIKEMBANGKAN DI PERAIRAN CILACAP DAN SEKITARNYA
}

\begin{abstract}
Ali Suman")
ABSTRAK

Penelitian yang dilakukan bertujuan untuk menentukan perioritas alat tangkap udang dogol (Metapenaeus ensis De Haan) yang layak dikermbangkan di perairan Cilacap dan sekitar. Penelitian ini dilakukan dari bulan Desember 2002 sampai dengan bulan Juni 2003. Metode yang digunakan dalam penelitian ini adalah metode skoring. Hasil penelitian menunjukkan bahwa alat tangkap yang layak dan ideal untuk dikembangkan berdasarkan pada perioritas ditinjau dari aspek biologi, aspek sosial, aspek teknis, dan aspek ekonomi adalah trammel net pasif, trammel net aktif trip harian, trammel net aktif trip mingguan, dan jaring dogol.
\end{abstract}

KATA KUNCl: alat tangkap, udang dogol, Cilacap

\section{ABSTRACT: Suitable fishing unit of endeavour shrimp to be developed in Cilacap and adjacent waters. By: Ali Suman}

The objective of this studis is to determine a priority for the suitable fishing unit of endeavour shrimp in Cilacap and adjacent waters. This studis was carried out from December 2002 to June 2003 and the evaluation was based on scoring method. The results show that the suitable fishing unit to be developed related to biological, social, technical, and economical aspects were passive trammel net, active trammel net in daily trip, active trammel net in weekly trip, and dogol net, subsequently in priority.

KEYWORDS: suitable fishing, endeavour shrimp, Cilacap

\section{PENDAHULUAN}

Eksploitasi sumber daya udang dogol di perairan Cilacap sampai dengan saat ini berlangsung bebas tanpa ada aturan dan kontrol yang jelas terhadap kegiatan penangkapan udang. Semua nelayan dan alat tangkap yang ada di perairan Cilacap bebas mengakses dan mengeksploitasi sumber daya ini setiap waktu. Bobot tekanan penangkapan ini terlihat dengan makin meningkat jumlah alat tangkap udang dogol yang beroperasi di perairan ini yaitu dari jumlah alat tangkap trammel net sekitar 1.211 unit pada tahun 1990 menjadi 1.577 unit pada tahun 2002 serta jumlah alat tangkap jaring dogol dari sekitar 135 unit pada tahun 1990 menjadi 195 unit pada tahun 2002. Hal ini, berarti telah terjadi penambahan sekitar $30 \%$ alat tangkap trammel net dan sekitar $44 \%$ jaring dogol dalam 13 tahun terakhir (Suman, 2004). Kondisi yang demikian membuat usaha penangkapan udang dogol yang dilakukan oleh nelayan Cilacap menjadi usaha yang tidak ekonomis dan tidak efisien. Agar pemanfaatan sumber daya udang dogol yang sedang dilakukan dapat dilakukan secara berkelanjutan, maka harus dilakukan penataan alat tangkap yang ada dengan melakukan seleksi teknologi penangkapan.
Seleksi teknologi penangkapan menurut Haluan \& Nurani (1988), dapat dilakukan melalui pengkajian-pengkajian aspek biotechnico socio economic approach. Oleh karena itu, ada 4 aspek yang harus dipenuhi oleh suatu jenis teknologi penangkapan udang yang akan dikembangkan, yaitu 1) bila ditinjau dari segi biologi tidak merusak atau mengganggu kelestarian sumber daya, 2) secara teknis efektif digunakan, 3) dari segi sosial dapat diterima masyarakat nelayan, dan 4) secara ekonomi teknologi tersebut menguntungkan. Selain itu, Monintja (1987) menambahkan bahwa teknologi penangkapan tersebut harus legal, menyerap tenaga kerja banyak serta menghasilkan pendapatan per nelayan yang memadai.

\section{BAHAN DAN METODE}

Penelitian ini dilakukan dari bulan Desember 2002 sampai dengan bulan Juni 2003 di perairan Cilacap dan sekitar (Gambar 1). Penelitian dilakukan dengan pengamatan langsung di pusatpusat pendaratan udang di perairan Cilacap dan sekitarnya (TPI PPSC, TPI Sidakaya, TPI

\footnotetext{
Peneliti pada Pusat Riset Perikanan Tangkap, Ancol-Jakarta
} 


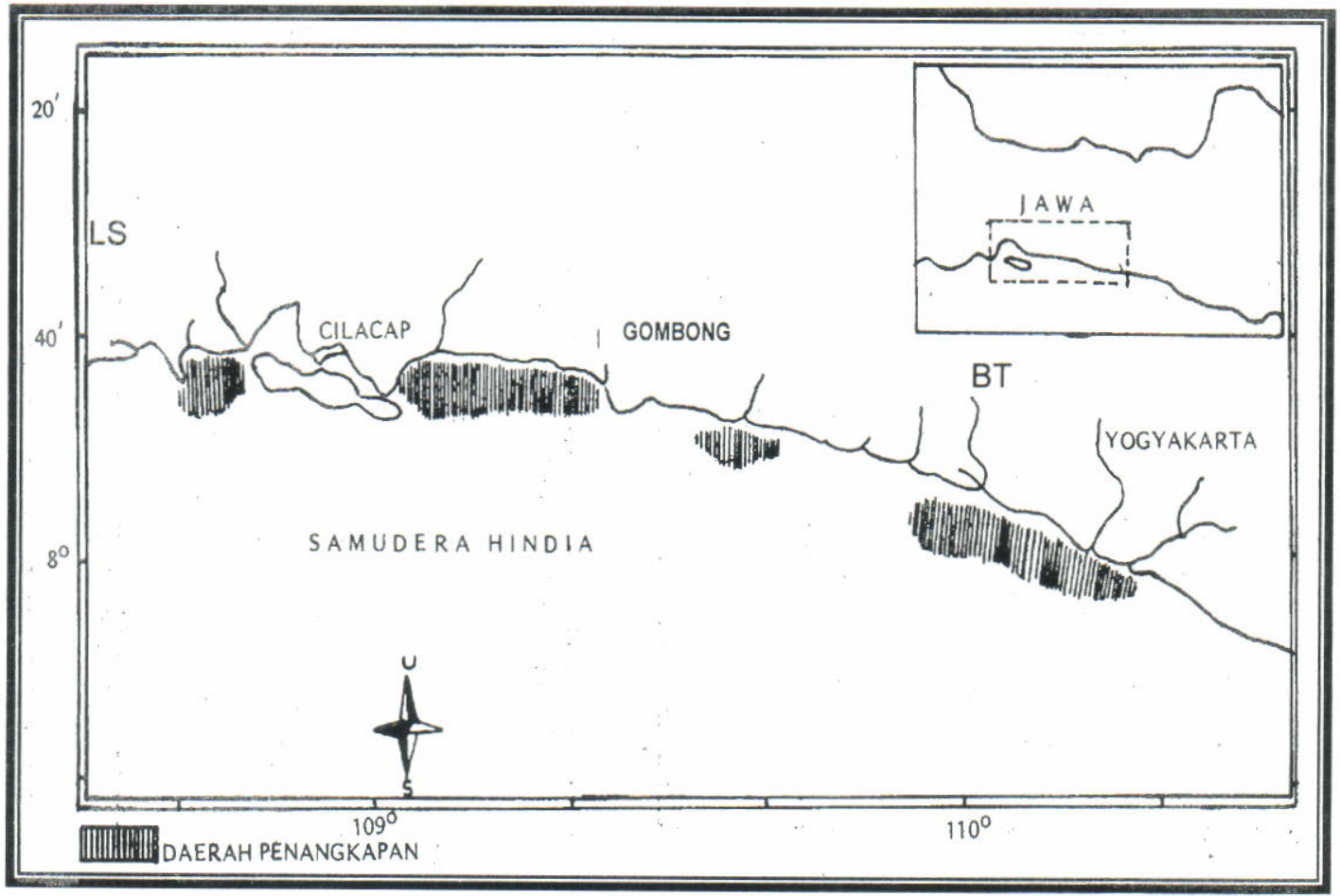

Gambar 1. Daerah penangkapan udang dogol di perairan Cilacap dan di sekitar.

Figure 1. Fishing ground in Cilacap and adjacent waters.

Argopeni, dan TPI Pangandaran). Seluruh pengumpulan data untuk keperluan pengkajian ini dilakukan dengan metode survei.

Untuk mendapatkan jenis alat yang mempunyai keragaan yang baik ditinjau dari aspek biologi, teknis, sosial, dan ekonomi sehingga merupakan alat tangkap yang cocok untuk pemanfaatan udang dogol secara berkelanjutan dilakukan analisis determinasi unit penangkapan udang dogol. Analisis determinasi yang digunakan dalam penelitian ini adalah model skoring (Monintja, 1987; Haluan \& Nurani, 1988) yang meliputi:

1. Aspek biologi yakni lama waktu musim penangkapan udang (bulan), persentase hasil tangkapan udang dari total hasil tangkapan (\%) dan ukuran udang target (ekor).

2. Aspek teknis yaitu mencakup hasil tangkapan per hari operasi $(\mathrm{kg})$, hasil tangkapan per tenaga kerja $(\mathrm{kg})$, hasil tangkapan per tahun $(\mathrm{kg})$, dan hasil tangkapan per jam operasi $(\mathrm{kg})$.

3. Aspek sosial yakni jumlah tenaga kerja per unit alat tangkap (orang), pendapatan tiap nelayan (Rp.), kemungkinan kepemilikan, dan alat tangkap bermasalah atau tidak.

4. Aspek ekonomi meliputi kriteria. efisiensi usaha yakni pendapatan kotor per biaya total tahunan, pendapatan bersih per biaya total tahunan, pendapatan kotor per biaya investasi dan pendapatan bersih per biaya investasi, serta kriteria efisiensi investasi yakni net present value, net benefit or cost, dan internal rate return (Kadariah \& Gray, 1999).

Metode skoring ini dapat digunakan untuk penilaian kriteria yang mempunyai satuan berbeda. Skoring diberikan dari nilai terendah sampai dengan nilai tertinggi. Untuk menilai semua kriteria atau aspek digunakan nilai tukar, sehingga semua nilai mempunyai standar yang sama. Unit usaha yang memperoleh nilai tertinggi berarti lebih baik daripada yang lain demikian pula sebaliknya. Untuk menghindari pertukaran yang terlalu banyak, maka digunakan fungsi nilai yang menggambarkan preferensi pengambil keputusan dalam menghadapi kriteria majemuk.

Standardisasi dengan fungsi nilai dapat dilakukan dengan menggunakan rumus dari Mangkusubroto \& Trisnadi (1985) sebagai berikut:

$$
\begin{aligned}
& V(X)=\frac{X-X_{0}}{X_{1}-X_{0}} \\
& n \\
& V(A)=\lambda V i(X i) \quad i=1,2,3, \\
& i=1
\end{aligned}
$$


di mana:

$\mathrm{V}(\mathrm{X}) \quad=$ fungsi nilai dari variabel $\mathrm{X}, \mathrm{X}$

$X, X=$ nilai variabel $X, X 1$

$X, X 1=$ nilai tertinggi pada kriteria $X, X_{0}$

$\mathrm{X}, \mathrm{Xo}=$ nilai terendah pada kriteria $\mathrm{X}, \mathrm{V}(\mathrm{A})$

$X, V(A)=$ fungsi nilai dari alternatif $A$ dan $V i(X i)$

$A \vee i(X i)=$ fungsi nilai dari alternatif pada kriteria ke-i

Karena $V$ adalah fungsi nilai yang mencerminkan preferensi pengambil keputusan, maka alternatif yang terbaik adalah alternatif yang memberikan nilai $V(X)$ tertinggi yang merupakan alat tangkap yang terpilih untuk dikembangkan di perairan Cilacap dan di sekitar.

\section{HASIL DAN BAHASAN}

Hasil

Walaupun hanya terdapat 2 jenis alat tangkap udang dogol yang utama di perairan Cilacap dan di sekitar tetapi dalam pengoperasian dapat dikategorikan menjadi 4 macam yaitu trammel net aktif trip harian, trammel net aktif tip mingguan, trammel net pasif, dan jaring jogol. Konsekuensi logis, maka hal ini akan menimbulkan perbedaan dalam aspek biologi, teknis, sosial, dan ekonomi. Oleh karena itu, maka dalam analisis berdasarkan pada aspek biologi, teknis, sosial, dan ekonomi dilakukan terhadap 4 kategori alat tangkap untuk menentukan pilihan yang paling layak bagi pemanfataan udang dogol secara berkelanjutan di perairan Cilacap dan di sekitar.

\section{Analisis aspek biologi}

Dalam penilaian aspek biologi, maka kriteria yang digunakan terhadap 4 jenis alat tangkap udang dogol ini adalah melihat efektivitas dan selektivitas unit penangkapan dalam menangkap udang target. Penilaian terhadap masing-masing kriteria tersebut dan urutan prioritas dari setiap unit alat tangkap disajikan pada Tabel 1.

Hasil penilaian terhadap aspek biologi unit penangkapan udang dogol setelah distandarisasi dengan menggunakan fungsi nilai (persamaan 1 dan 2), secara keseluruhan dapat dilihat pada Tabel 2.

Berdasarkan pada Tabel 2 yaitu dari hasil penilaian aspek biologi unit penangkapan udang dogol dengan menggunakan fungsi nilai, didapatkan trammel net aktif trip mingguan sebagai prioritas pertama, disusul trammel net aktif trip harian di posisi ke-2, sedang trammel net pasif di urutan ke-3, dan jaring dogol di urutan ke-4.

Tabel 1. Penilaian aspek biologi unit penangkapan udang dogol di perairan Cilacap dan sekitar Table 1. Biological aspect of endeavour shrimp catching unit in Cilacap and adjacent waters

\begin{tabular}{|c|c|c|c|}
\hline \multirow{2}{*}{ Alat tangkap } & \multicolumn{3}{|c|}{ Kriteria penilaian } \\
\hline & $\mathrm{X} 1$ & $\mathrm{X} 2$ & X3 \\
\hline Trammel net aktif $\mathrm{A}$ & 10 & 30 & 35 \\
\hline Trammel net aktif B & 8 & 25 & 50 \\
\hline Trammel net pasif & 8 & 20 & 60 \\
\hline Jaring Dogol & 8 & 20 & 70 \\
\hline
\end{tabular}

Tabel 2.

Standarisasi aspek biologi unit penangkapan udang dogol di perairan Cilacap dan di sekitar

Table 2. Standarization of biological aspect of endeavour shrimp catching unit in Cilacap and adjacent waters

\begin{tabular}{ccccc}
\hline \multirow{2}{*}{ Alat tangkap } & \multicolumn{3}{c}{ Kriteria } & V(A) \\
\cline { 2 - 4 } & $\mathbf{V 1}(\mathbf{X} 1)$ & $\mathbf{V 2}(\mathbf{X 2})$ & $\mathbf{V 3}(\mathbf{X} \mathbf{3})$ & 3,00 \\
TNA & 1,00 & 1,00 & 1,00 & 1,07 \\
TNB & 0,00 & 0,50 & 0,57 & 0,29 \\
TNC & 0,00 & 0,00 & 0,29 & 0,00 \\
JD & 0,00 & 0,00 & 0,00 & Trammel net aktif trip harian TNC = Trammel net pasif; JD
\end{tabular}
jaring dogol 


\section{Analisis aspek teknis}

Aspek teknis merupakan aspek yang berhubungan dengan pengoperasian alat penangkapan udang dogol, yaitu apakah secara teknis alat tersebut efisien atau tidak sewaktu dioperasikan. Kriteria yang digunakan dalam aspek ini adalah produksi yang dihasilkan tiap unit penangkapan dalam 1 tahun, produksi per trip, produksi per tenaga kerja, dan produksi per jam operasi. Pada Tabel 3 disajikan hasil penilaian analisis teknis unit penangkapan udang dogol di perairan Cilacap dan di sekitar.

Selanjutnya, dilakukan standarisasi kriteria aspe teknis dengan menggunakan fungsi nilai (persamaz 1 dan 2) dan didapat hasil seperti pada Tabel 4.

Penilaian aspek teknis alat tangkap udang dogol setelah distandarisasi seperti disajikan pada Tabel 4 menempatkan alat tangkap trammel net aktif trip mingguan pada urutan prioritas pertama. Alat tangkap trammel net aktif trip harian dan jaring dogol menempati urutan prioritas ke-2 secara bersama-sama dan alat tangkap trammel net pasif menempati posisi terakhir yaitu pada urutan prioritas ke-3.

\section{Analisis Aspek Sosial}

Analisis aspek sosial meliputi penilaian terhadap kriteria aspek sosial yaitu penyerapan tenaga kerja per unit penangkapan, penerimaan nelayan per unit penangkapan, kemungkinan kepemilikan, serta melihat apakah alat tangkap tersebut menimbulkan masalah. Nilai pada penyerapan kerja dilihat dari jumlah tenaga kerja yang digunakan setiap unit penangkapan, sedang nilai pada kriteria pendapatan nelayan per tahun diperoleh dari sistem bagi hasil antar nelayan per unit penangkapan. Untuk nilai pada kriteria kemungkinan kepemilikan unit penangkapan udang oleh nelayan diperoleh dari pembagian antara pendapatan nelayan per tahun dengan modal investasi dari setiap unit penangkapan, sementara kriteria penilaian alat tangkap yang menimbulkan masalah sosial, seperti bentrokan sesama nelayan, dilakukan berdasarkan pada wawancara. Apabila menimbulkan masalah diberikan skor 5 dan apabila tidak diberikan skor 0 . Pada Tabel 5 diterakan penilaian aspek sosial unit penangkapan udang dogol di perairan Cilacap dan sekitar.

Tabel 3. Penilaian analisis aspek teknis unit penangkapan udang dogol di perairan Cilacap dan

Table 3. Valuation of technical aspect analysis of endeavour shrimp catching unit in Cilacap and adjacent waters

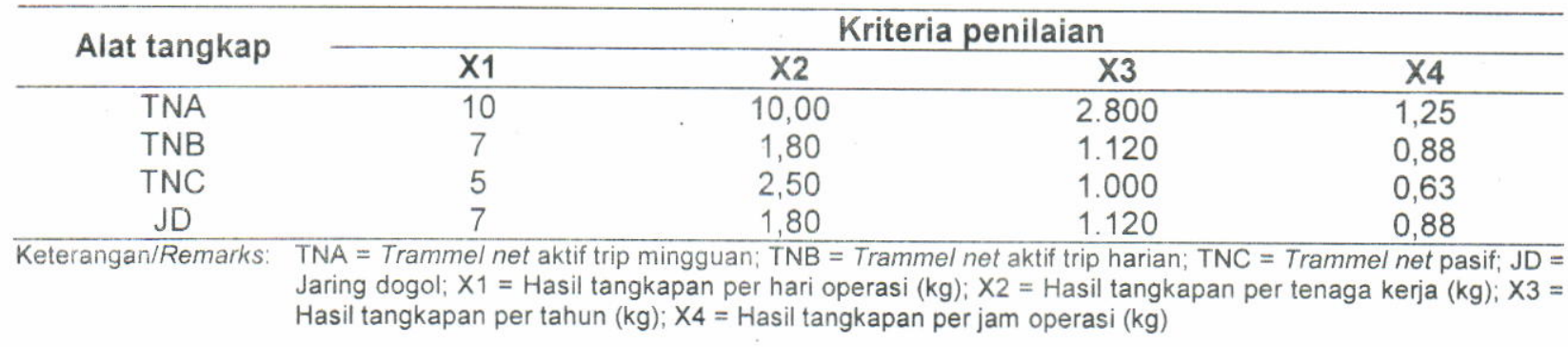

Tabel 4. Standarisasi penilaian aspek teknis unit penangkapan udang dogol di perairan Cilacap dan di sekitar

Table 4. The standardization of valuation on technical aspect of endeavour shrimp catching unit in Cilacap and adjacent waters

\begin{tabular}{|c|c|c|c|c|c|}
\hline \multirow{2}{*}{ Alat tangkap } & \multicolumn{4}{|c|}{ Kriteria } & \multirow{2}{*}{$V(A)$} \\
\hline & $\mathrm{V} 1(\mathrm{X} 1)$ & $\mathrm{V} 2(\mathrm{X} 2)$ & V3(X3) & $V 4(X 4)$ & \\
\hline TNA & 1,00 & 1,00 & 1,00 & 1,00 & 4,00 \\
\hline TNB & 0,40 & 0,00 & 0,07 & 0,40 & 0,87 \\
\hline JD & 0,40 & 0,00 & 0,07 & 0,40 & 0,87 \\
\hline TNC & 0,00 & 0,09 & 0,00 & 0,00 & 0,09 \\
\hline
\end{tabular}


Tabel 5 .

Penilaian analisis sosial pada unit penangkapan udang dogol di perairan Cilacap dan di sekitar

Table 5. Social analysis valuation of endeavour shrimp fishing unit in Cilacap and adjacent waters

\begin{tabular}{ccccc}
\hline \multirow{2}{*}{ Alat tangkap } & \multicolumn{4}{c}{ Kriteria penilaian } \\
\cline { 2 - 5 } & $\mathbf{X 1}$ & $\mathbf{X 2}$ & $\mathbf{X 3}$ & $\mathbf{X 4}$ \\
\hline TNA & 7 & 3.674 .285 & 0,06 & 0 \\
TNB & 4 & 3.902 .000 & 0,16 & 5 \\
TNC & 2 & 9.000 .000 & 0,54 & 5 \\
JD & 4 & 2.372 .000 & 0,11 & 0
\end{tabular}

Keterangan/Remarks: TNA $=$ Trammel net aktif trip mingguan; TNB = Tramme/ net aktif trip harian; TNC $=$ Trammel net pasif; JD $=$ Jaring dogol; $X 1=$ Jumlah tenaga kerja (orang); $X 2=$ Pendapatan nelayan $(\mathrm{Rp}.) ; X_{3}=$ Kemungkinan kepemilikan; $X 4=$ Alat tangkap bermasalah atau tidak

Tabel 6.

Standarisasi penilaian aspek sosial terhadap unit penangkapan udang dogol di perairan Cilacap dan di sekitar

Table 6. Standarization of valuation on social aspect of endeavour shrimp fishing unit Cilacap and adjacent waters

\begin{tabular}{cccccc}
\hline \multirow{2}{*}{ Alat tangkap } & \multicolumn{3}{c}{ Kriteria } & V(A) \\
\cline { 2 - 5 } TNC & V1(X) & V2(X2) & V3(X3) & V4(X4) & \\
\hline TNB & 0,00 & 1,00 & 1,00 & 1,00 & 3,00 \\
TNA & 0,40 & 0,23 & 0,21 & 1,00 & 1,85 \\
JD & 1,00 & 0,19 & 0,00 & 0,00 & 1,19 \\
\hline
\end{tabular}

Keterangan/Remarks: $\quad$ TNA $=$ Trammel net aktif trip mingguan; TNB $=$ Tramme/ net aktif trip harian; TNC $=$ Trammel net pasif; JD $=$ jaring dogol

Dari Tabel 5 di atas dilakukan standarisasi kriteria aspek sosial dengan menggunakan fungsi nilai (persamaan 1 dan 2) dan didapat hasil seperti pada Tabel 6.

Penilaian terhadap aspek sosial secara keseluruhan pada Tabel 6 menempatkan alat tangkap trammel net pasif pada prioritas pertama, disusul oleh alat tangkap trammel net aktif trip mingguan pada prioritas ke-2, alat tangkap trammel net aktif trip harian pada posisi ke-3, dan alat tangkap jaring dogol pada prioritas terakhir pada posisi ke-4. Urutan prioritas ini terlihat banyak dipengaruhi oleh jumlah tenaga kerja yang akan berpengaruh langsung terhadap pendapatan nelayan per tahun dan kemungkinan kepemilikan. Semakin banyak tenaga kerja pada setiap unit penangkapan udang dogol akan mengakibatkan pendapatan per nelayan dan kemungkinan kepemilikan akan semakin mengecil.

\section{Analisis Aspek Ekonomi}

Penilaian aspek ekonomi meliputi penilaian terhadap kriteria aspek ekonomi, yaitu efisiensi usaha dan efisiensi investasi. Efisiensi usaha meliputi pendapatan kotor per biaya total tahunan, pendapatan bersih per biaya total tahunan, pendapatan kotor per biaya investasi, dan pendapatan bersih per biaya investasi. Efisiensi investasi meliputi nilai net present value, nilai net benefit cost ratio, dan nilai internal rate of return (Kadariah \& Gray, 1999). Penilaian analisis aspek ekonomi kriteria efisiensi usaha alat tangkap udang dogol disajikan pada Tabel 7.

Tabel 7. Penilaian analisis aspek ekonomi untuk kriteria efisiensi usaha unit terhadap penangkapan udang dogol di perairan Cilacap dan sekitar

Table 7. Valuation of economic aspect analysis for the effort efficiency criteria on endeavour shrimp fishing unit in Cilacap and adjacent waters

\begin{tabular}{ccccc}
\hline \multirow{2}{*}{ Alat tangkap } & \multicolumn{4}{c}{ Kriteria penilaian } \\
\cline { 2 - 5 } & $\mathbf{X 1}$ & $\mathbf{X 2}$ & $\mathbf{X 3}$ & $\mathbf{X 4}$ \\
\hline TNA & 1,20 & 0,20 & 2,30 & 0,30 \\
TNB & 1,40 & 0,40 & 2,10 & 0,70 \\
TNC & 1,40 & 0,40 & 2,70 & 0,80 \\
JD & 1,50 & 0,50 & 1,50 & 0,50 \\
\hline
\end{tabular}

Keterangan/Remarks: $\cdot$ TNA $=$ Trammel net aktif trip mingguan; TNB $=$ Trammel net aktif trip harian; TNC $=$ Trammel net pasif; JD $=$ Jaring dogol; $X 1=$ Pendapatan kotor per biaya total tahunan; $X 2=$ Pendapatan bersih per biaya total tahuan: $X_{3}=$ Pendapatan kotor per biaya investasi; $X_{4}=$ Pendapatan bersih per biaya investasi 
Selanjutnya, data pada Tabel 7 dilakukan standarisasi dengan menggunakan fungsi nilai (persamaan 1 dan 2) dan didapatkan hasil seperti tersaji pada Tabel 8.

Berdasarkan pada penilaian terhadap masingmasing kriteria dalam efisiensi usaha, memperlihatkan alat tangkap yang menempati prioritas ke-1 alat tangkap trammel net pasif, sedang yang menempati prioritas ke-2 trammel net aktif trip harian. Alat tangkap jaring dogol menempati prioritas ke-3 dan trammel net aktif trip mingguan menempati prioritas terakhir yaitu urutan ke-4.
Selanjutnya, dari penilaian efisiensi investasi dari kriteria net present value, dan nilai menempatkan alat tangkap trammel net aktif trip harian pada prioritas ke-1, sedangkan dari kriteria nilai net benefit cost ratio, dan internal rate of return menempatkan alat tangkap trammel net pasif pada prioritas ke-1. Secara rinci penilaian masing-masing kriteria investasi serta urutan prioritas tersaji pada Tabel 9.

Standarisasi hasil penilaian aspek ekonomi kriteria investasi pada Tabel 9 dilakukan berdasarkan pada fungsi nilai (persamaan 1 dan 2) dan didapatkan hasil seperti tersaji pada Tabel 10.

Tabel 8. Standarisasi penilaian aspek ekonomi untuk kriteria efisiensi waktu terhadap unit

Table 8. Standarization of economic aspect valuation for efficiency effort criteria on endeavour penangkapan udang dogol di perairan Cilacap dan sekitar shrimp fishing unit in Cilacap and adjacent waters

\begin{tabular}{|c|c|c|c|c|c|}
\hline \multirow{2}{*}{ Alat tangkap } & \multicolumn{4}{|c|}{ Kriteria } & \multirow[b]{2}{*}{$V(A)$} \\
\hline & V1(X1) & V2(X2) & V3(X3) & V4(X4) & \\
\hline TNC & 0,67 & 0,75 & 1,00 & 1,00 & 3,42 \\
\hline TNB & 0,67 & 0,75 & 0,50 & 0,80 & 2,72 \\
\hline JD & 1,00 & 1,00 & 0,00 & 0,40 & 2,40 \\
\hline TNA & 0,00 & 0,00 & 0,67 & 0,00 & 0,67 \\
\hline
\end{tabular}

Tabel 9. Penilaian aspek ekonomi untuk kriteria efisiensi investasi terhadap unit penangkapan udang dogol di perairan Cilacap dan sekitar

Table 9. Economic aspect valuation for invesment efficiency criteria on endeavour shrimp unit in Cilacap and adjacent waters

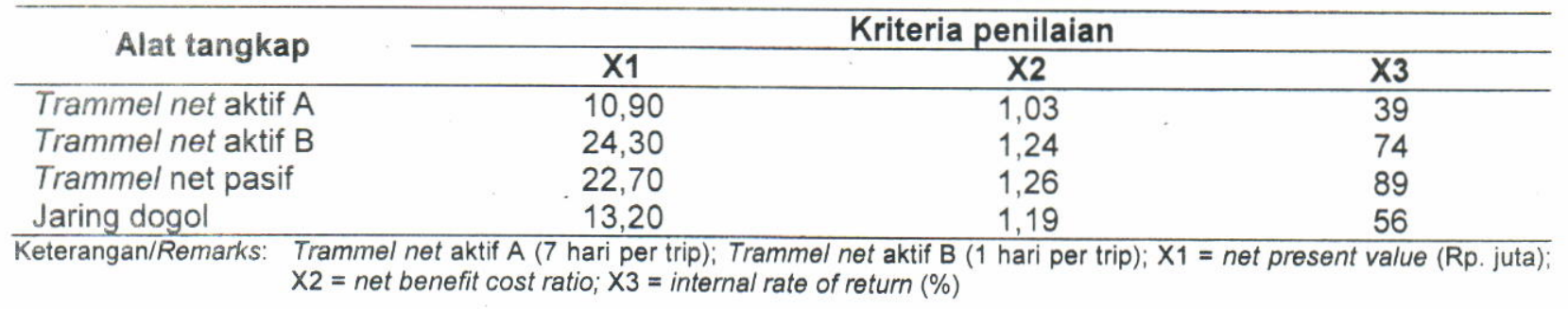

Tabel 10. Standarisasi aspek ekonomi untuk kriteria efisiensi investasi terhadap unit penangkapan. udang dogol di perairan Cilacap dan sekitar

Table 10. Standarization of economic aspect for invesment efficiency criteria on endeavour shrimp fishing unit in Cilacap and adjacent waters

\begin{tabular}{ccccc}
\hline Alat tangkap & \multicolumn{3}{c}{ Kriteria } & V(A) \\
\cline { 2 - 4 } & $\mathbf{V 1}(\mathbf{X} 1)$ & $\mathbf{V 2}(\mathbf{X 2})$ & $\mathbf{V 3}(\mathbf{X} \mathbf{3})$ & 2,88 \\
\hline TNC & 0,88 & 1,00 & 1,00 & 2,61 \\
TNB & 1,00 & 0,91 & 0,70 & 1,21 \\
JD & 0,17 & 0,70 & 0,34 & 0,00 \\
TNA & 0,00 & 0,00 & 0,00 &
\end{tabular}

Keterangan/Remarks: TNA = Trammel net aktif trip mingguan; TNB = Trammel net aktif trip harian; TNC = Trammel net pasif; JD = jaring dogol 
Secara keseluruhan, penilaian aspek ekonomi efisiensi investasi pada Tabel 10 mendapatkan alat tangkap trammel net pasif pada peringkat ke1, trammel net aktif trip harian pada urutan ke-2, jaring dogol pada urutan ke-3, dan trammel net aktif trip mingguan pada urutan ke-4.

Analisis Aspek Biologi, Teknis, Sosial, dan Ekonomi

Tujuan determinasi unit penangkapan udang adalah untuk mendapatkan jenis alat tangkap udang dogol yang mempunyai keragaan (performance) yang baik ditinjau dari aspek biologi, teknis, ekonomi, dan sosial sehingga merupakan alat tangkap yang cocok untuk dikembangkan bagi pemanfaatan sumber daya udang dogol secara berkelanjutan. Pada Tabel 11 disajikan hasil skoring yang dilakukan terhadap 4 kategori alat tangkap udang dogol yang ada di perairan Cilacap dan di sekitar berdasarkan pada analisis aspek biologi, teknis, sosial, dan ekonomi.

Berdasarkan pada Tabel 11 selanjutnya dilakukan standarisasi dengan menggunakan fungsi nilai (persamaan 1 dan 2) pada penilaian aspek biologi, teknis, sosial, dan ekonomi dan didapatkan hasil seperti disajikan pada Tabel 12.

Tabel 11. Hasil analisis penilaian aspek untuk biologi, teknis, sosial, dan ekonomi terhadap unit penangkapan udang dogol di perairan Cilacap dan sekitar

Table 11. Result of valuation analysis for biological, technical, social, and economic aspect on endeavour shrimp fishing unit in Cilacap and adjacent waters

\begin{tabular}{cccccc}
\hline \multirow{2}{*}{ Alat tangkap } & \multicolumn{5}{c}{ Kriteria penilaian } \\
\cline { 2 - 6 } & $\mathbf{X 1}$ & $\mathbf{X 2}$ & $\mathbf{X 3}$ & $\mathbf{X 4}$ & $\mathbf{X 5}$ \\
\hline TNA & 3,00 & 4,00 & 1,19 & 0,67 & 0,00 \\
TNB & 1,07 & 0,87 & 1,85 & 2,72 & 2,61 \\
TNC & 0,29 & 0,09 & 3,00 & 3,42 & 2,88 \\
JD & 0,00 & 0,87 & 0,49 & 2,40 & 1,21
\end{tabular}

Keterangan/Remarks: TNA $=$ Trammel net aktif trip mingguan; TNB $=$ Trammel net aktif trip harian; TNC $=$ Trammel net pasif; JD $=$ Jaring dogol; $\mathrm{X} 1=$ Aspek biologi; $\mathrm{X} 2=$ Aspek teknis; $\mathrm{X} 3=$ Aspek sosial; $\mathrm{X} 4=$ Aspek ekonomi kriteria efisiensi usaha; $X 5$ = Aspek ekonomi kriteria efisiensi investasi

Tabel 12. Standarisasi aspek untuk biologi, teknis, sosial, dan ekonomi terhadap unit penangkapan udang dogol di perairan Cilacap dan sekitar

Table 12. Standarization for biological, technical, social, and economic aspect on endeavour shrimp fishing unit in Cilacap and adjacent waters

\begin{tabular}{|c|c|c|c|c|c|c|}
\hline \multirow{2}{*}{$\begin{array}{c}\text { Alat } \\
\text { tangkap }\end{array}$} & \multicolumn{5}{|c|}{ Kriteria } & \multirow{2}{*}{$V(A)$} \\
\hline & $\mathrm{V} 1(\mathrm{X} 1)$ & V2(X2) & V3(X3) & $\mathrm{V} 4(\mathrm{X} 4)$ & V5(X5) & \\
\hline TNC & 0,10 & 0,00 & 1,00 & 1,00 & 1,00 & 3,10 \\
\hline TNB & 0,36 & 0,19 & 0,54 & 0,75 & 0,91 & 2,75 \\
\hline TNA & 1,00 & 1,00 & 0,28 & 0,00 & 0,00 & 2,28 \\
\hline JD & 0,00 & 0,19 & 0,00 & 0,63 & 0,42 & 1,24 \\
\hline
\end{tabular}

Keterangan/Remarks: TNA $=$ Trammel net aktif trip mingguan; TNB $=$ Trammel net aktif trip harian; TNC $=$ Trammel net pasif; JD = Jaring dogol

Hasil standarisasi yang dilakukan terhadap 4 kategori alat tangkap udang dogol pada Tabel 12 dapat terseleksi alat tangkap yang layak untuk dikembangkan dalam rangka pemanfaatan sumber daya udang dogol secara berkelanjutan di perairan Cilacap dan di sekitar. Alat tangkap trammel net pasif terlihat menempati prioritas ke- 1 sebagai alat tangkap yang layak dikembangkan, trammel net aktif trip harian pada urutan ke-2, trammel net aktif trip mingguan urutan ke-3, dan jaring dogol sebagai pilihan terakhir (ke-4) untuk dikembangkan. Urutan prioritas ini dapat digunakan sebagai bahan pertimbangan dalam menentukan pengembangan alat tangkap di perairan Cilacap dan di sekitar, namun sebagai dasar harus tetap ditunjang informasi tentang potensi sumber daya udang dogol serta upaya optimum yang diizinkan.

\section{BAHASAN}

Hasil dari analisis aspek biologis, teknis, sosial, dan ekonomi terhadap unit alat tangkap udang dogol yang ada di perairan Cilacap dan di sekitar, menempatkan alat tangkap trammel net pasif pada 
urutan ke-1 alat tangkap yang layak dikembangkan, disusul trammel net aktif trip harian pada urutan ke-2, trammel net aktif trip mingguan pada urutan ke-3, dan alat tangkap udang dogol pada urutan terakhir yaitu pada urutan ke-4.

Trammel net pasif adalah alat tangkap udang dogol yang layak dikembangkan pada prioritas utama. Dalam analisis ekonomi dan sosial alat tangkap ini menempati urutan ke-1, yang berarti alat tangkap ini merupakan alat tangkap yang menghasilkan pendapatan tertinggi bagi nelayan dan di samping itu memberi peluang yang besar untuk memiliki sendiri alat tangkap tersebut. Dengan demikian, alat tangkap trammel net pasif ini memberikan kontribusi yang besar dalam meningkatkan kesejahteraan nelayan sehingga dalam jangka panjang akan menjamin pemanfaatan udang dogol secara berkelanjutan. Alat tangkap trammel net ini memang hanya menempati posisi ke-3 dalam analisis biologi dan teknis, tetapi hal ini bukan menggambarkan ketidakbaikan dalam menangkap udang dogol. Justru dengan posisi operasi penangkapan dalam keadaan pasif akan dapat menjaga habitat udang dogol dengan baik, karena tidak ada proses pengadukan dasar laut pada waktu penangkapan udang dogol. Selain itu, operasional penangkapan yang bersifat pasif di jalur I adalah alat tangkap legal sesuai dengan SK Mentan No.392/1999.

Trammel net aktif trip harian yang berada pada prioritas ke-2 adalah alat tangkap udang dogol yang cukup baik, karena dapat menangkap udang yang ukuran lebih baik, dengan demikian akan menghasilkan hasil tangkapan dengan ukuran udang yang lebih besar. Alat tangkap ini merupakan alat tangkap yang selalu menempai urutan ke-2 dalam aspek teknis, sosial, dan ekonomi, yang berarti alat tangkap ini benar cukup baik dikembangkan karena menguntungkan, di samping itu alat ini juga tidak menimbulkan masalah dengan alat tangkap lain.

Trammel net aktif trip mingguan yang layak dikembangkan pada prioritas ke-3 adalah alat tangkap udang dogol yang cukup efektif dalam menangkap udang dari segi biologi dan teknis, tetapi tidak efisien dari aspek sosial dan ekonomi. Dengan demikian, alat tangkap ini tidak begitu baik dalam usaha meningkatkan pendapatan nelayan. Selain itu, kelemahan alat tangkap trammel net aktif trip mingguan adalah pelanggaran jalur penangkapan yang sering dilakukan karena beroperasi di jalur I untuk menangkap udang. Izin operasional alat ini adalah menangkap di jalur III, tetapi karena target operasi di jalur I, maka dalam operasi lebih banyak melanggar peraturan. Itu sebab alat tangkap ini dalam jangka panjang akan menimbulkan masalah dengan alat tangkap ikan lain, karena posisi sebagai alat tangkap ilegal di jalur I penangkapan.

Jaring dogol adalah alat tangkap udang dogol yang layak dikembangkan pada prioritas terakhir atau ke-4. Alat tangkap ini terlihat kurang selektif sehingga cenderung mengganggu kelestarian sumber daya karena udang yang tertangkap yang berukuran kecil, yang berarti tidak memberi kesempatan kepada populasi udang untuk melakukan penambahan baru. Selain itu, alat tangkap ini menangkap udang target dalam persentase yang lebih kecil sehingga meningkatkan jumlah hasil tangkap sampingan yang kurang ekonomis, yang tidak menguntungkan secara ekonomi maupun kelestarian sumber daya. Alat tangkap jaring dogol adalah alat tangkap yang sering menimbulkan masalah dengan alat tangkap ikan lain, karena tumpang tindih lahan pengoperasian serta cenderung kurang disukai nelayan karena perawatan dan pengoperasian lebih sulit. Dengan demikian, alat tangkap ini sering menimbulkan konflik sosial serta kerawanan sosial lain, sehingga stabilitas pemanfaatan udang di suatu wilayah tidak terjamin. Hasil tangkapan yang kurang memadai baik per hari, per tenaga kerja, dan per tahun menunjukkan alat tangkap ini kurang efektif untuk menangkap udang dan secara umum alat tangkap ini menempati urutan ke-4 dalam menghasilkan produksi udang dogol. Selain itu, alat tangkap ini menghasilkan pendapatan per hari, per biaya investasi, dan pendapatan bersih per biaya investasi yang lebih rendah dari alat tangkap udang dogol lain, oleh karena itu kurang berprospek untuk kesinambungan pemanfaatan dan peningkatan kesejahteraan nelayan.

\section{KESIMPULAN DAN SARAN}

1. Alat tangkap udang dogol yang layak dan ideal dikembangkan di perairan Cilacap dan di sekitar menurut urutan prioritas adalah trammel net pasif pada urutan ke-1, trammel net aktif trip harian pada urutan ke-2, trammel net aktif trip mingguan pada urutan ke-3, dan jaring dogol pada urutan ke-4.

2. Urutan prioritas ini direkomendasikan sebagai bahan pertimbangan dalam menentukan pengembangan alat tangkap udang dogol di perairan Cilacap dan di sekitar, namun sebagai dasar harus tetap ditunjang informasi tentang potensi sumber daya udang dogol serta upaya optimum yang diizinkan. 


\section{DAFTAR PUSTAKA}

Haluan, J. \& T. W. Nurani. 1988. Penerapan metode skoring dalam pemilihan teknologi penangkapan ikan yang sesuai untuk dikembangkan di suatu wilayah perairan. Buletin Jurusan PSP. Hal.3-16.

Kadariah, K. L. \& C. Gray. 1999. Pengantar evaluasi proyek. Edisi LPFE-UI. Jakarta. Hal.39-76.

Mangkusubroto, K. \& C. L. Trisnadi. 1985. Analisis keputusan pendekatan sistem data manajemen usaha dan proyek. Ganeca Exact. Bandung. 271 hal.

Monintja, D. R. 1987. Beberapa teknologi pilihan untuk pemanfaatan sumber daya hayati laut di Indonesia. Buletin PSP. Vol.1 No.1: 14-26.

Suman, A. 2004. Pola pemanfaatan sumber daya udang dogol (Metapenaeus ensis de Haan) secara berkelanjutan di perairan Cilacap dan sekitarnya. Disertasi Doktor pada Sekolah Pasca Sarjana. Institut Pertanian Bogor. Bogor. 
